\title{
Perceived Barriers towards Physical Activity among Female University Students
}

\author{
Nor Zaihan Mat Hasan @ Mat Hussin, Annurizal Anuar, Naffisah Mohd \\ Hassan \& Siti Noorsuriani Maon
}

To Link this Article: http://dx.doi.org/10.6007/IJARBSS/v11-i4/9660

DOI:10.6007/IJARBSS/v11-i4/9660

Received: 05 February 2021, Revised: 07 March 2021, Accepted: 24 March 2021

Published Online: 15 April 2021

In-Text Citation: (Hussin et al., 2021)

To Cite this Article: Hussin, N. Z. M. H. @ M., Anuar, A., Hassan, N. M., \& Maon, S. N. (2021). Perceived Barriers towards Physical Activity among Female University Students. International Journal of Academic Research in Business and Social Sciences, 11(4), 191-201.

Copyright: (c) 2021 The Author(s)

Published by Human Resource Management Academic Research Society (www.hrmars.com)

This article is published under the Creative Commons Attribution (CC BY 4.0) license. Anyone may reproduce, distribute, translate and create derivative works of this article (for both commercial and non-commercial purposes), subject to full attribution to the original publication and authors. The full terms of this license may be seen at: http://creativecommons.org/licences/by/4.0/legalcode

Vol. 11, No. 4, 2021, Pg. 191 - 201

Full Terms \& Conditions of access and use can be found at http://hrmars.com/index.php/pages/detail/publication-ethics 


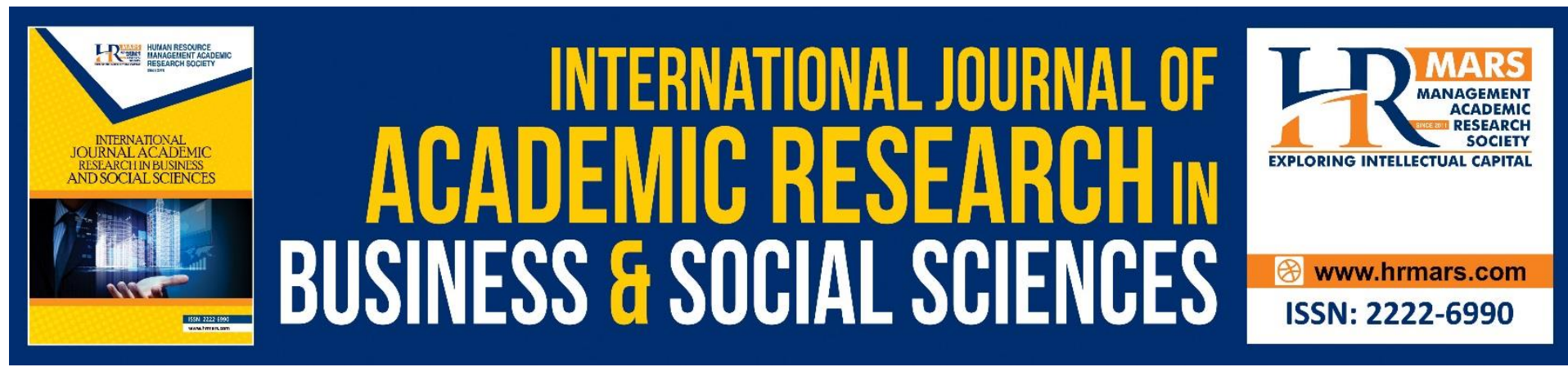

\title{
Perceived Barriers towards Physical Activity among Female University Students
}

\author{
Nor Zaihan Mat Hasan @ Mat Hussin, Annurizal Anuar, \\ Naffisah Mohd Hassan \& Siti Noorsuriani Maon
}

Faculty of Business and Management, Universiti Teknologi MARA (UiTM) Cawangan Selangor, Kampus Puncak Alam, Bandar Puncak Alam, 42300 Selangor, Malaysia

Email: naffi885@uitm.edu.my

\begin{abstract}
Physical activity is defined as any bodily movement produced by skeletal muscles that requires energy expenditure. Lack of regular physical activity at young age able to increase the risk to get cardiovascular disease, cancer, and osteoporosis later in life. The physical activity index among Malaysian teens revealed that they were more active than the rest of the ages at the age of 21 . However, at 22 years of age and above, these young people attempt to decrease their PA, and at this age, most of them are university students. Therefore, the objective of this study is mainly to examine differences in internal and external attributes between active and inactive participation in physical activity among female students. A crosssectional study was conducted using convenience sampling technique. Students completed a questionnaire focusing on the barriers in physical activity. Comparison analysis was then used to examine the differences in mean scores between active and less active respondents. Both external and internal barriers in physical activity were found statistically significant difference in mean scores. External barriers in physical activity were higher values of mean score compared to internal barriers. Lack of time due to social and family responsibilities was considered as most important barriers in physical activity. Future research at large scale and targeting other population are needed in order to help nation achieved SDGs 2030 goal 3 by improving healthy lifestyle and promote well-being for all at all ages.
\end{abstract}

Keywords: Physical Activity, University Students, Barriers in Physical Activity

\section{Introduction}

Physical activity (PA) is defined as any bodily movement produced by skeletal muscles that requires energy expenditure including activities undertaken while working, playing, carrying out household chores, travelling and engaging in recreational pursuits (World Health Organization, 2018) Lack of PA at young age able to increase the risk to get cardiovascular disease, cancer, and osteoporosis later in life, overweight and obesity, and increase the chances of them to be physically inactive during adulthood (Jose et al., 2011; World Health Organization, 2010). Modernization and hectic everyday life have shifted from the traditional kind of human being. (Zhao et al., 2007) . In a study from 23 countries, the prevalence of physical inactivity was $41.4 \%$ ranging from $21.9 \%$ to $80.6 \%$ (Pengpid S. et al., 2015). According 
to Bray and Born (2004), one third of active students in high school became insufficiently active upon transitioning to university life. Researchers have suggested that the university students have similar issues of physical inactivity. A survey of the PA index among Malaysian teens revealed that they were more active than the rest of the ages at the age of 21 . However, at 22 years of age and above, these young people attempt to decrease their PA, and at this age, most of them are university students (Rajappan et al., 2015). Surveys by university students and staff suggest a perceived lack of access to desirable places, such as parks and playgrounds, lack or poor condition of pavements and bike paths, as well as safety, are concerns and obstacles to people's participation in physical activity (Lian et al, 2016). Therefore, the aim of this study was to examine differences in internal and external attributes between active and inactive participation in physical activity among female students.

\section{Literature Review}

Physical Activities (PA)

The term PA is the distinction in movements that PA is scheduled, organized, routine and seeks to enhance or preserve the physical activity elements whilst the word of exercise relates to tasks that are done at free time, to drive to and from areas that have health benefits. But both of these have a function to improve people's health (WHO, 2018). A study in Asian Social Sciences (2013), which looked at the physical activity index among Malaysian teenagers, found that at the age of 21 , they were more involved than the rest of the population, however at the age of 22 and above, these young people lowered their PA.

In recent years, it has shown that there are some barriers to PA-approved students entering university due to lack of PA involvement. According to Saadan et al. (2015), there are two barriers to participation in the PA, which are internal and external barriers. The internal barriers were classified into three categories: lack of capacity, lack of motivation, lack of selfefficiency or lack of self-confidence (Oluyinka \& Endozo, 2019), while the external barriers are lack of money, lack of social support and lack of time. External barriers apply to factors outside the control of the person, while internal barriers are factors that influence the decision of the person (Korkiakangas et al., 2009)

\section{Internal Attributes}

A study by Saleem et al. (2018) showed that students involved in a number of activities at the respective schools, which is 199 (41.5 per cent) of respondents reported feeling tired and exhausted as a significant cause of physical inactivity. Due to a busy schedule, they become short of energy and want to rest instead of doing PA. The research respondents also decided that they were too stressed and tire to do PA after school hours. Other than that, lack of motivation also as one of the key mediums that leads people to engage less in PA (Rajappan et al., 2015). Belanger et al., (2015) has stated that there are many reasons for lack of motivation. It could have been due to a weak desire, laziness and it could have been due to a lack of self-esteem. In 2015, Saadan et al. conducted a study that found that adolescent girls noted that lack of self-efficacy and lack of self-confidence was the main reason and barrier to PA. As a result, they are concerned about how they look when they exercise because they lack self-confidence about their ability to perform the PA. 


\section{External Attributes}

One of the common external barriers to PA was the lack of resources and facilities (Justine et al., 2013; Lowe et al., 2019). Creating an active environment in the open space school or college, forests, parks and playgrounds are positively related to PA levels among children and adolescents at school and college. Researchers point out that the most serious problems are not only the declining PA of students, but also the lack of social support to participate in physical activity. It is a significant and growing problem that students are currently facing. Parents, teachers, and other key role models are increasingly encouraged to incorporate PA into the daily lifestyle of students (Lisinskiene \& Juskeliene, 2019). Furthermore, the lack of PA among students is attributed to their busy lives, and studies have indicated that university students have related physical inactivity problems (Fagaras et al., 2015). In Japan, for example, the most important potential obstacles that impact factors influencing PA is lack of time (Ibrahim et al., 2013). Although lack of time due to conflicting classes, such as homework or social events may be seen as an intrinsic obstacle to PA involvement, the assumption that there is not enough time could be attributed to the low degree of importance with which PA was considered to be linked to certain competing demands (Vu-Nguyen et al., 2016)

\section{Methodology}

\section{Data collection and participants}

A convenience sampling technique was employed in this present research. Data has been obtained through a self-administrated structured survey question online. The researcher used an established questionnaire from previous study in this study (Oluyinka \& Endozo, 2019). At this stage, there were 28 items under internal and external attributes to be examined. A questionnaire was produced, asking respondents to rate the attributes that affect physical activities on a 5-point scale with anchors of "Strongly disagree" to "Strongly agree". The three components of internal factors; including lack of energy, lack of motivation and lack of self-confidence. The other three components of external factors; in which include lack of resources, lack of social support and lack of time. The overall total of the categories' scores that are used to figure out the total 28 internal and external barriers. Data was then collected, and a total of 262 responses were managed to be obtained and were valid for data analysis purposes.

\section{Data analysis}

Descriptive statistic was used to study the obtained data using IBM SPSS version 26. Frequencies, mean and standard deviation were used to describe the demographic background of respondents. To ensure goodness of measures, convergent validity and reliability for the instrument were applied. Both descriptive and inferential statistics were applied using statistical package for social science software (IBM SPSS version 26.0). Simple frequencies were used to study the characteristics of respondents. Comparison analysis was conducted to assess active and non-active students, particularly in internal and external attributes that affect physical activities.

\section{Findings}

\section{Description of the respondents' profile}

Table 1 shows the demographic characteristics of the respondents. Overall, majority of the respondents were female (72.6\%), not married $(93.9 \%)$ and more than half of the 
respondents were at range between $22-24$ years old. There were $38.5 \%$ from lower level semester; including Year 1, Year 2 and Year 3; and more than half (61.5\%) were upper level semester; i.e. Year 4 onwards.

Table 1 Demographic profile

\begin{tabular}{|c|c|c|c|c|c|c|c|c|}
\hline No & Variable & & $\begin{array}{c}\text { Total } \\
(n=262)\end{array}$ & & $\begin{array}{l}\text { tive } \\
127 ; \\
8 \%)\end{array}$ & & $\begin{array}{l}\text { active } \\
51.5 \%)\end{array}$ & $p$-value \\
\hline \multirow[t]{3}{*}{1} & Age & $19-21$ & $53(20.2)$ & 25 & 19.7 & 28 & 20.7 & \\
\hline & & $22-24$ & $165(63)$ & 88 & 69.3 & 77 & 57 & 0.039 \\
\hline & & $>25$ & $44(16.8)$ & 14 & 11 & 30 & 22.2 & \\
\hline \multirow[t]{6}{*}{2} & Semester & 1 & $53(202)$ & 25 & 19.7 & 28 & 20.7 & \\
\hline & & 2 & $30(11.5)$ & 19 & 15 & 11 & 8.1 & \\
\hline & & 3 & $16(6.1)$ & 7 & 5.5 & 9 & 6.7 & 0.089 \\
\hline & & 4 & $25(9.5)$ & 8 & 6.3 & 17 & 12.6 & \\
\hline & & 5 & $40(15.3)$ & 22 & 17.3 & 18 & 13.3 & \\
\hline & & 6 & $98(37.4)$ & 46 & 36.2 & 52 & 38.8 & \\
\hline
\end{tabular}

Male students were found more active than female students. Students from range age between 22 to 24 years were reported had participated actively in regular physical activity and students were single more active. Students from lower level semester were reported not active in physical activity, however students from upper level semester were had active participation.

Data results reported that out of 262 respondents; nearly half of them (48.8\%) participated actively in physical activity and the other half students (50.1\%) did not participate in physical activity. Details of the survey's findings are shown in Table 2.

Students, who actively participated and less participated in physical activity, had disagreed and strongly disagreed $(n=89 ; 70.1 \%)$ that the exercise was unpleasant and too tiring activities. However, students; either actively or less participated in physical activity strongly disagreed and disagreed that they had no energy as much as they could exercise; then thought of other recreational activities with friends was even more entertaining than exercise; did not consider exercise to have a positive effect on their health; were concerned about their appearance when exercising; and did not think about their ability to exercise. 
INTERNATIONAL JOURNAL OF ACADEMIC RESEARCH IN BUSINESS AND SOCIAL SCIENCES Vol. 11, No. 4, 2021, E-ISSN: 2222-6990 @ 2021 HRMARS

Table 2

Frequency of Internal and External Attributes towards to Physical Activity Involvement

$(\mathrm{N}=262)$

\begin{tabular}{|c|c|c|c|c|c|c|c|}
\hline & \multirow[t]{2}{*}{ ITEM } & \multicolumn{2}{|c|}{ ALL } & \multicolumn{2}{|c|}{$\begin{array}{l}\text { Active } \\
(n=127)\end{array}$} & \multicolumn{2}{|c|}{$\begin{array}{l}\text { Less Active } \\
(\mathrm{n}=135)\end{array}$} \\
\hline & & M & SD & $\mathbf{M}$ & SD & M & SD \\
\hline & INTERNAL BARRIERS & 2.166 & 0.66 & 1.976 & 0.599 & 2.344 & 0.668 \\
\hline Q1 & $\begin{array}{l}\text { I have been thinking about exercising is } \\
\text { difficult and too tiring. }\end{array}$ & 2.385 & 0.875 & 2.149 & 0.746 & 2.601 & 0.931 \\
\hline \multirow[t]{2}{*}{ Q2 } & $\begin{array}{l}\text { I have no energy as much as to be able to } \\
\text { do exercise }\end{array}$ & 2.16 & 0.819 & 1.968 & 0.734 & 2.341 & 0.856 \\
\hline & Sum of Perceived of Lack of Energy & 4.545 & 1.497 & 4.118 & 1.27 & 4.948 & 1.585 \\
\hline Q3 & $\begin{array}{l}\text { I have been thinking about other } \\
\text { recreational activities with my friends are } \\
\text { more entertaining than exercise. }\end{array}$ & 2.16 & 0.819 & 1.968 & 0.734 & 2.341 & 0.857 \\
\hline \multirow[t]{2}{*}{ Q4 } & $\begin{array}{l}\text { I have not been thinking about exercise } \\
\text { has positive effects on my health. }\end{array}$ & 1.832 & 0.902 & 1.646 & 0.782 & 2.007 & 0.973 \\
\hline & Sum of Perceived of Lack of Motivation & 3.992 & 1.414 & 3.614 & 1.303 & 4.348 & 1.426 \\
\hline Q5 & $\begin{array}{l}\text { I have been worried about my looks when } \\
\text { I exercise. }\end{array}$ & 2.313 & 1.09 & 2.149 & 0.909 & 2.467 & 1.22 \\
\hline \multirow[t]{3}{*}{ Q6 } & $\begin{array}{l}\text { I have not been thinking about my ability } \\
\text { to exercise. }\end{array}$ & 2.145 & 0.999 & 1.976 & 0.895 & 2.304 & 1.067 \\
\hline & $\begin{array}{l}\text { Sum of Perceived of Lack of Self- } \\
\text { confidence }\end{array}$ & 4.458 & 1.785 & 4.126 & 1.589 & 4.77 & 1.904 \\
\hline & EXTERNAL BARRIERS & 2.418 & 0.783 & 2.113 & 0.753 & 2.705 & 0.7003 \\
\hline Q7 & $\begin{array}{l}\text { There is no fitness center that I could get } \\
\text { to. }\end{array}$ & 2.694 & 1.151 & 2.457 & 1.067 & 2.918 & 1.185 \\
\hline \multirow[t]{2}{*}{ Q8 } & $\begin{array}{l}\text { I have no exercise equipment at home } \\
\text { that I can use. }\end{array}$ & 2.641 & 1.223 & 2.315 & 1.206 & 2.945 & 1.161 \\
\hline & Sum of Perceived of Lack of Resources & 5.336 & 2.132 & 4.772 & 2.052 & 5.867 & 2.076 \\
\hline Q9 & $\begin{array}{l}\text { My family or friends do not encourage me } \\
\text { to exercise. }\end{array}$ & 1.901 & 0.981 & 1.653 & 0.791 & 2.133 & 1.084 \\
\hline \multirow[t]{2}{*}{ Q10 } & $\begin{array}{l}\text { My parents give academic success priority } \\
\text { over exercise. }\end{array}$ & 2.145 & 1.062 & 1.992 & 1.087 & 2.289 & 1.021 \\
\hline & Sum of Perceived of Lack of Support & 4.046 & 1.919 & 3.646 & 1.693 & 4.422 & 2.046 \\
\hline Q11 & $\begin{array}{l}\text { I have no leisure time for exercise because } \\
\text { of my busy lesson schedule. }\end{array}$ & 2.542 & 1.143 & 2.149 & 1.032 & 2.911 & 1.123 \\
\hline \multirow[t]{2}{*}{ Q12 } & $\begin{array}{l}\text { I have no leisure time for exercise because } \\
\text { of my social and family responsibilities. }\end{array}$ & 2.584 & 1.127 & 2.11 & 1.085 & 3.029 & 0.977 \\
\hline & Sum of Perceived of Lack of Time & 5.126 & 2.122 & 4.259 & 1.899 & 5.941 & 1.999 \\
\hline
\end{tabular}

Note: $M=$ Mean; $S D=$ Standard Deviation

Table 2 describes perceived barriers to physical activity of the respondents. Differences in mean scores of perceived barriers between active respondents and less active respondents. Less active respondents have higher mean scores in perceived barriers of 
physical activity towards all dimensions of both internal and external barriers. The total mean score of external barriers was reported to be higher than the mean score of the internal barriers. Data findings revealed that lack of time was the highest mean value among less active respondents $(M=5.941 ; S D=1.999)$; however, lack of resources was the highest mean value among active respondents $(M=4.722 ; S D=2.052)$. It was reported that less active respondents did not have time for physical activity due to their social and family responsibilities ( $M=3.029 ; S D=0.977)$. Referring to the internal barriers, lack of energy was the highest mean value among less active respondents ( $M=4.948$; $S D=1.585)$; though, lack of selfconfidence was the highest mean value among active respondents ( $M=4.126 ; S D=1.589)$. It was reported that less active respondents believed the exercise was a difficult and tiring activity (M=2.601; $\mathrm{SD}=0.931)$.

Table 3 shows the differences in attributes, including internal and external attributes, between respondents who had active participation in physical activity and less active participation in physical activity. An independent-samples t-test was conducted to compare both external and internal attributes between the two groups of respondents: active participation and less active participation in physical activity.

Table 3 Differences between Active and Non-active Students

\begin{tabular}{|c|c|c|c|c|c|c|c|c|c|c|c|}
\hline $\begin{array}{c}\text { Variab } \\
\text { le }\end{array}$ & $\begin{array}{l}\text { Ty } \\
\text { pe }\end{array}$ & $M$ & SD & $d f$ & $\mathrm{t}$ & $p$ & $\begin{array}{c} \\
\text { Differe } \\
\text { nce }\end{array}$ & $\begin{array}{c}\text { SE } \\
\text { Differe } \\
\text { nce }\end{array}$ & \multicolumn{2}{|c|}{$95 \% \mathrm{Cl}$} & $\begin{array}{c}\text { Cohen' } \\
\text { S D }\end{array}$ \\
\hline \multirow{3}{*}{$\begin{array}{c}\text { Intern } \\
\text { al } \\
\text { barrie } \\
\text { rs }\end{array}$} & & & & \multirow{3}{*}{$\begin{array}{c}26 \\
0\end{array}$} & & & \multirow{3}{*}{-.3681} & \multirow{3}{*}{.0785} & UL & $\mathrm{LL}$ & \multirow{3}{*}{0.580} \\
\hline & 1 & $\begin{array}{c}1.97 \\
6\end{array}$ & .599 & & $\begin{array}{c}4.68 \\
8\end{array}$ & $\begin{array}{c}.00 \\
0\end{array}$ & & & $\begin{array}{c}- \\
.523\end{array}$ & \multirow[t]{2}{*}{-.213} & \\
\hline & 2 & $\begin{array}{c}2.34 \\
4\end{array}$ & .668 & & & & & & & & \\
\hline \multirow[t]{2}{*}{$\begin{array}{c}\text { Extern } \\
\text { al } \\
\text { barrie } \\
\text { rs }\end{array}$} & 1 & $\begin{array}{c}2.11 \\
3\end{array}$ & .753 & $\begin{array}{c}26 \\
0\end{array}$ & $\begin{array}{c}- \\
6.59 \\
3\end{array}$ & $\begin{array}{c}.00 \\
0\end{array}$ & -.5291 & 0.898 & $\begin{array}{c}- \\
.768\end{array}$ & -.415 & 0.813 \\
\hline & 2 & $\begin{array}{c}2.70 \\
4\end{array}$ & .700 & & & & & & & & \\
\hline
\end{tabular}

Note: 1 = Active; 2 = Non-active

This study results found that there was a statistically significant difference in internal attributes scores for respondents who active participation in physical activity $(M=2.006$, $S D=0.619)$ and less active participation in physical activity $(M=1.976, S D=0.599) ; t(260)=-$ $4.688, p<0.05$. The magnitude of the differences in the means (mean difference $=-0.368,95 \%$ $\mathrm{Cl}:-0.523$ to -0.213 ) has large effect (eta squared $=0.580$ ).

In terms of external attributes, data findings indicate a statistically significant difference in scores for respondents who had actively participated $(M=2.113, S D=0.753)$ and less active participated $(M=2.696, S D=0.678)$ in regular physical activity; $t(260)=-6.593$, $p<0.05$. The magnitude of the differences in the means (mean difference $=-0.529,95 \% \mathrm{Cl}$ : - 
0.768 to -0.415 ) has large effect (eta squared $=0.813$ ). Therefore, these results reveal that level of attributes certainly influence the participation in physical activity among university students. On average, when students have positive external and internal attributes, their level participation in physical activity tend to be improved.

\section{Discussion}

Regular physical activity among young people particularly in university student provides health benefits (Reiner et al., 2013). The present study aimed to examine differences in internal and external attributes between active and inactive participation in physical activity among female students. The results indicated that nearly half of the participants at range age between $22-24$ years old from upper-level semester were had active participation in physical activity. The other half of students from lower-level semester were reported not active in physical activity because they had no energy as much as they could exercise (Saleem et al., 2018); then thought of other recreational activities with friends was even more entertaining than exercise; did not consider exercise to have a positive effect on their health; were concerned about their appearance when exercising; and did not think about their ability to exercise. This is in accordance with the scientific literature which shows that this educational modification could suppose important changes in adolescents, especially psychological and emotional changes (Ullrich-French et al., 2013).

This study findings revealed that both perceived external and internal barriers in physical activity were statistically significant differences in mean scores between active and less active respondents. It was shown that perceived external barriers considered as more important than perceived internal barriers. In terms of external barriers, data findings indicate a statistically significant difference in scores for respondents who had actively participated and less active participated in regular physical activity. Lack of time was indicated as most important barriers among less active female respondents due to their social and family responsibilities. This result is consistent with Anjali \& Sabharwal (2018) result that lack of time has emerged as a key barrier to involvement in physical activity, along with technologyrelated behaviors, such as peers, parents, and teachers. On the other hand, lack of resources was the most significant among active respondents. Concerning to the access of facilities or resources, almost all the female respondents indicated that there has a fitness center that they can go but they agreed that they do not have any exercise tools at home. These findings are in accordance with previous study by Flora \& Faulkner (2007) . She found that, poor physical way at existing equipment could lead to a barrier in participation of female in physical activity.

Referring to the internal barriers, lack of energy was the most significant among less active respondents; though, lack of self-confidence was indicated as a key barrier among active respondents. It was reported that less active respondents believed the exercise was a difficult and tiring activity. According to Ajzen \& Madden, (1986), attitudes are affected by social norms, which then influence intentions and in turn behavior. If the social norm is not to be physically active and not to enjoy the physical connection of being physically active, then an individual's attitude towards physical activity may become more negative, with the knock-on effect of reduced exercise intention and ultimately behavior. 


\section{Conclusion}

In conclusion, this study highlights that barriers of physical activity certainly influence the participation in physical activity among university students. On average, when students have positive external and internal attributes, their level participation in physical activity tend to be improved. This will contribute to a healthy life style among universities students with the objective of enhancing their well-being and development for the whole life. However, the study has several limitations. First, the sample was small because the researchers only targeted on a particular university, namely Universiti Teknologi MARA in Puncak Alam, Selangor. Next, the study emphasized merely only on three factors for internal and external barriers, respectively. Despite the limitations, it is recommended that further research should be carried out at large scale and targeting other population are needed in order to help nation achieved SDGs 2030 goal 3 by improving healthy lifestyle and promote well-being for all at all ages.

\section{Acknowledgement}

We would like to express our sincere gratitude to the Faculty of Business and Management, Universiti Teknologi MARA (UiTM) Selangor, Puncak Alam Campus, for their support, guidance and contributions.

\section{References}

Ajzen, I., \& Madden, T. J. (1986). Prediction of goal-directed behavior: Attitudes, intentions, and perceived behavioral control. Journal of Experimental Social Psychology. https://doi.org/10.1016/0022-1031(86)90045-4

Anjali \& Sabharwal, M. (2018). Perceived barriers of young adults for participation in physical activity. Current Research in Nutrition and Food Science. https://doi.org/10.12944/CRNFSJ.6.2.18

Belanger, M., Sabiston, C. M., Barnet, T. A., O'Loughlin, E., Ward, S., Contreras, G. \& O'Loughlin, J. (2015). Number of Years of Participation in Some, But Not All, Types of Physical Activity During Adolescence Predicts Level of Physical Activity in Adulthood. International Journal of Behavioral Nutrition and Physical Activity, 12 (1),76

Bray, S. R., \& Born, H. A. (2004). Transition to university and vigorous physical activity: Implications for health and psychological well-being. Journal of American College Health, 52(4), 181-188. doi:10.3200/JACH.52.4.181-188

Fagaras, S. P., Radu, L. E., \& Vanvu, G. (2015). The Level of Physical Activity of University Students. Procedia - Social and Behavioral Sciences.

https://doi.org/10.1016/j.sbspro.2015.07.094

Flora, P. K., \& Faulkner, G. E. J. (2007). Physical activity: An innovative context for intergenerational programming. Journal of Intergenerational Relationships. https://doi.org/10.1300/J194v04n04_05

Ibrahim, S., Karim, N. A., Oon, N. L., \& Ngah, W. Z. W. (2013). Perceived physical activity barriers related to body weight status and sociodemographic factors among Malaysian men in Klang Valley. BMC Public Health. https://doi.org/10.1186/1471-2458-13-275

Jose, K. A., Blizzard, L., Dwyer, T., McKercher, C., \& Venn, A. J. (2011). Childhood and adolescent predictors of leisure time physical activity during the transition from adolescence to adulthood: A population based cohort study. International Journal of Behavioral Nutrition and Physical Activity. https://doi.org/10.1186/1479-5868-8-54

Justine, M., Azizan, A., Hassan, V., Salleh, Z., \& Manaf, H. (2013), Barriers to Participation in 
Physical Activity Exercise Among Middle-Aged and Elderly Individuals, 2013; 54(10): 581586 doi:10.11622/smedj.2013203

Korkiakangas, E. E., Alahuhta, M. A., \& Laitinen, J. H. (2009). Barriers to regular exercise among adults at high risk or diagnosed with type 2 diabetes: A systematic review. Health Promotion International. https://doi.org/10.1093/heapro/dap031

Lian, T. C., Bonn, G., Han, Y. S., Choo, Y. C., \& Piau, W. C. (2016). Physical activity and its correlates among adults in Malaysia: a cross-sectional descriptive study. PLoS One, 11(6), e0157730

Lisinskiene, A., \& Juskeliene, V. (2019). Links between Adolescents' Engagement in Physical Activity and Their Attachment to Mothers, Fathers, and Peers. International Journal of Environmental Research and Public Health, 16(5), 866. doi: 10.3390/ijerph16050866

Lowe. R., Stockt T. V. D., Lee. M, \& Knott, C. (Eds.), (2019). Barriers to Physical Activity. Physiopedia. Retrieved from website: https://www.physiopedia.com/index.php?title=Barriers_to_Physical_Activity\&oldid $=203107$

Oluyinka, S. \& Endozo, A. (2019). Factors Affecting Physical Activity Participation Among University Students. Journal Of Social Science Research. 14, (Mar. 2019), 3161-3170.

Pengpid, S., Peltzer, K., Kassean, H. K., Tsala Tsala, J. P., Sychareun, V., \& MüllerRiemenschneider, F. (2015). Physical inactivity and associated factors among university students in 23 low-, middle- and high-income countries. Int J Public Health. 2015 Jul;60(5):539-49. doi: 10.1007/s00038-015-0680-0. Epub 2015 Apr 30. PMID: 25926342.

Rajappan, R., Selvaganapathy, K., \& Liew, L. (2015). PHYSICAL ACTIVITY LEVEL AMONG UNIVERSITY STUDENTS: A CROSS SECTIONAL SURVEY. International Journal of Physiotherapy and Research. https://doi.org/10.16965/ijpr.2015.202

Reiner, M., Niermann, C., Jekauc, D., \& Woll, A. (2013). Long-term health benefits of physical activity - A systematic review of longitudinal studies. In BMC Public Health. https://doi.org/10.1186/1471-2458-13-813

Saadan, R., Jano, Z., Sidek, S., Bokhari, M., \& Rosli, N. (2015). Perceived Barriers in Physical Activities. Journal of Human Capital Development(JHCD) 8, no. 1 (2015): 39-46.

Saleem, F., Bashaar, M., Hassali, M. A., Haque, N., Iqbal, Q., Ahmad, A., Khan, M. U., Ahmad, F. D., Thawani, V., \& Hashemi, T. (2018). Assessment of barriers to physical activities among university students in Malaysia. Pharm Pharmacol Int J, 6(6), 468-473

Sandu, P., Chereches, R. M., Baba, C. O., Revnic, R. N., \& Mocean, F. (2018). Environmental influences on physical activity - Romanian youths' perspectives. Children and Youth Services Review, 95, 71-79. doi: 10.1016/j.childyouth.2018.10.020

Ullrich-French, S., Cox, A. E., \& Bumpus, M. F. (2013). Physical activity motivation and behavior across the transition to university. Sport, Exercise, and Performance Psychology. https://doi.org/10.1037/a0030632

Vu-Nguyen, K., Kukaswadia, A., \& Moher, D. (2016), Evidence Brief: Barriers to physical activity for children and youth in Ontario, Ontario Agency for Health Protection and Promotion (Public Health Ontario), ISBN: 978-1-4606-7816-9

World Health Organization. (2010). Global Recommendations on Physical Activity for Health WHO Library Cataloguing-in-Publication Data Global recommendations on physical activity for health. In World Health Organization.

World Health Organization. (2018). Global action plan on physical activity 2018-2030: more active people for a healthier world. In Journal of Policy Modeling.

Zhao, Y., Sigmund, E., Sigmundová, D., \& Lu, Y. (2007). Comparison of Physical Activity Between Olomouc and Beijing University Students Using an International Physical 
INTERNATIONAL JOURNAL OF ACADEMIC RESEARCH IN BUSINESS AND SOCIAL SCIENCES Vol. 11, No. 4, 2021, E-ISSN: 2222-6990 @ 2021 HRMARS

Activity Questionnaire. Acta Universitatis Palackianae Olomucensis. Gymnica. 